\title{
Production and Characterization of Energy Materials with Adsorbent Properties by Hydrothermal Processing of Corn Stover with Subcritical $\mathrm{H}_{2} \mathrm{O}$
}

\author{
N.T. Machado ${ }^{1,2,3,}$, D.A.R. de Castro ${ }^{2,3}$, L.S. Queiroz ${ }^{4}$, M.C. Santos ${ }^{3}$ and C.E.F. da Costa ${ }^{4}$ \\ ${ }^{1}$ Leibniz-Institüt für Agrartechnik Potsdam-Bornin e.V, Department of Postharvest Technology, Max-Eyth- \\ Allee 100, Potsdam 14469, Germany \\ ${ }^{2}$ Laboratory of Separation Processes and Applied Thermodynamic (TERM@), Faculty of Chemical \\ Engineering-UFPA, Brazil \\ ${ }^{3}$ Graduate Program of Natural Resources Engineering-UFPA, Rua Augusto Corrêia No. 1, CEP: 66075-900, \\ Cx. P. 8619, Belém-Pará, Brazil \\ ${ }^{4}$ Laboratory of Catalysis and Oleochemistry, Faculty of Chemistry-UFPA, Rua Augusto Corrêia No. 1, CEP: \\ 66075-900, Cx. P. 8619, Belém-Pará, Brazil
}

\begin{abstract}
This work aims to investigate the effect of temperature on the process performance of hydrothermal processing (HTC) of corn Stover with subcritical $\mathrm{H}_{2} \mathrm{O}$ and on the morphology of solid products. The experiments were carried out at 200,225 and $250^{\circ} \mathrm{C}$, reaction time of 240 minutes, heating rate of $2.0^{\circ} \mathrm{C} / \mathrm{min}$, and biomass to water ratio of 1:10, using a pilot scale stirred tank reactor (STR) of 5 gallon, operating in batch mode. The process performance analyzed by computing the yields of solid and liquid reaction products (RLP). The aqueous phase $\left(\mathrm{H}_{2} \mathrm{O}+\mathrm{RLP}\right)$ was physicochemical analyzed for $\mathrm{pH}$ and total carboxylic acids, expressed as total acetic acid content. The chemical compositions of carboxylic acids, furfural, and hydroxymethylfurfural (HMF) in the aqueous phase determined by GC-MS and HPLC. The results showed solid yields ranging from 57.39 to $35.82 \%$ (wt.), and liquid reaction products (RLP) yields ranging from 39.53 to $54.59 \%$ (wt.). The solid phase products were characterized by scanning electron microscopy (SEM), energy dispersive X-ray spectroscopy (EDX), and X-ray diffraction (XRD). The chemically activated (2.0 M $\mathrm{NaOH}$ ) solid phase energy material obtained by $\mathrm{HTC}$ at $250^{\circ} \mathrm{C}$, applied as adsorbent to investigate the capacity and/or efficiency to adsorb acetic acid from 1.0 to $4.0 \mathrm{~g} / \mathrm{L}$ model solutions at $25^{\circ} \mathrm{C}$. The solid phase yield decreases along with the temperature, showing an inflection region between 200 and $225^{\circ} \mathrm{C}$, whereas a drastic change takes place, while that of liquid phase increases, showing also a drastic change between 200 and $225^{\circ} \mathrm{C}$. The total acetic acid content of aqueous phase varied from 4064 to $5387 \mathrm{mg} / \mathrm{L}$, while the $\mathrm{pH}$ from 3.77 to 3.91 . The $\mathrm{GC}$ analysis identified the presence of volatile carboxylic acids, particularly acetic acid, in concentrations between 4020 and $5040 \mathrm{mg} / \mathrm{L}$. HPLC identified the presence of furfural and hydroxymethylfurfural, whose concentrations decrease exponentially and linearly along with the temperature between 686.7 and 0.0 , and 443.9 and $0.0 \mathrm{mg} / \mathrm{L}$, respectively, being both compounds not detectable at 250 ${ }^{\circ} \mathrm{C}$. The elemental/ultimate analysis of solid products shows that carbon content increases, while the oxygen and hydrogen contents decrease, along with the temperature. The $\mathrm{H} / \mathrm{C}$ and $\mathrm{O} / \mathrm{C}$ ratios decrease linearly as process temperature increases, and the high heating value $(\mathrm{HHV})$ of solid reaction products, an energy densified material, changes sharply between 200 and $225^{\circ} \mathrm{C}$, showing an increase with temperature. The SEM, EDX, and XDR indicates a change on the morphology and mineralogical phases present in solid reaction products with temperature, particularly at $250{ }^{\circ} \mathrm{C}$. The activated solid phase has proven to be very selective to adsorb acetic acid, showing that recovery of acetic acid from hydrothermal carbonization/liquefaction aqueous solutions is feasible by using a multistage-stage adsorption process in series.
\end{abstract}

Keywords: $\mathrm{HTC}$, Subcritical $\mathrm{H}_{2} \mathrm{O}$, Corn Stover, Energy Materials, Morphology, Adsorption.

\section{INTRODUCTION}

There exists numerous sources of cellulosic-rich renewable materials for bioconversion (woody industry wastes, forage crops, crop residues, etc.) [1]. However, only a few cellulose-rich materials are available in large quantities, except crops residue [2], to support process in industrial scale for bio-conversion of cellulose-rich materials. Among these, corn Stover is one of the most

*Correspondence Address to this author at the Laboratory of Separation Processes and Applied Thermodynamics (TERM@), Faculty of Chemical Engineering, Federal University of Pará, Belém-Pará-Brazil, Campus Profissional I, Institute of Technology, Rua Augusto Corrêa No. 1, Guamá, CEP: 66075-110, Caixa Postal 479, Brazil; Tel: 0055-91-32017295;

Fax: 0055-91-32017291; E-mail: machado@ufpa.br potentials renewable materials (biomass) for bioconversion [3].

Corn Stover, an agro-industrial residue left after harvesting of corn grains, produces around $25-30 \%$ (wt.) of leafy fraction (leaf + husk + sheaths) and $70-$ $75 \%$ of fibrous and hard material (stalk + cobs) [4]. It is the most abundant and cheap source of biomass available for bioconversion that may be partially removed from agricultural fields, if proper management technology is used $[5,6]$.

By considering that world corn production for the 2015/2016*, crop years reached 969.6 MMT [7], and the fact that corn Stover accounts for $70 \%$ (wt.) of corn 
plant mass [4], large amounts of corn Stover are generate yearly [3]. Stover has been applied to produce ethanol [8-12], butanol [13], briquettes and pellets [14, 15], and until carbonaceous rich materials [16-19]. The pretreatment processes of corn Stover for bioconversion purposes includes wet oxidation [9], SC$\mathrm{CO}_{2}$ [10], microorganism [12], pyrolysis [16-18], hot compressed water [18-20], steam [21], diluted acid solution [22], and ammonia-based pretreatments [11, 23, 24]. Among these, hydrothermal processing of lignocellulose-rich biomass using hot compressed water is a promising technique [25], particularly for biomass containing high moisture content, such as activated sewage sludge [26-29], as the biomass moisture content has no limit of application by hydrothermal treatment [30]. Other applications of hydrothermal treatment/processing of biomass with high moisture content includes agricultural crops residues, such as corn Stover with moisture content between $50-60 \%$ (wt.) [4], as reported elsewhere [1719].

The hydrothermal biomass transformation using subcritical water as reaction media, a non-toxic, environmental friendly, and cheap solvent [31], is referred hydrothermal carbonization (HTC) when the main reaction product is a carbonaceous-rich solid phase and hydrothermal liquefaction when a liquid reaction product dominates [32]. As the temperature of hot compressed water increases up to $300^{\circ} \mathrm{C}$, the ionic product of water increases by three orders of magnitude $\left(\mathrm{K}_{\mathrm{H} 2 \mathrm{O}(298 \mathrm{~K})}=10^{-14} \mathrm{~mol}^{2} \mathrm{~L}^{-2}, \mathrm{~K}_{\mathrm{H} 2 \mathrm{O}(573 \mathrm{~K})}=10^{-11}\right.$ $\mathrm{mol}^{2} \mathrm{~L}^{-2} ; \mathrm{K}_{\mathrm{H} 2 \mathrm{O}}\left(573 \mathrm{~K} / \mathrm{K}_{\mathrm{H} 2 \mathrm{O}}(298 \mathrm{~K})=10^{3}\right)$ [32], thus catalyzing chemical reactions such as hydrolysis and organic compounds degradation without aid a catalyst [33]. In addition, the viscosity of hot condensed water strongly decreases with increasing temperature, enhancing the mass transfer process not only at the fluid-solid interface, but also within the porous solid matrix [31]. The state conditions of subcritical water $(T, P)$, mainly the temperature, determines the compositional characteristics and proportions of reaction products (gases, aqueous, and solid phase) [30-32].

The major drawbacks of hydrothermal processing of biomass with hot compressed water are the relative high water-to-biomass ratio that makes the process energy intensive, as water has a great heat capacity, and the fact that large amounts of process water is generate as liquid reaction products, containing toxic and hazardous substances such as furfural, hydroxymethylfurfural, and phenols [34-40]. Recently, studies reported the use of process water generated by hydrothermal treatments of biomass [40-42], but processes are either time consuming or energy intensive if one aims to process biomass in industrial scale.

Despite the increasing number of studies on hydrothermal processing of biomass with hot compressed water [18-20, 25-30, 32, 34-41, 43-51], only a few studies investigated the effect of process conditions on morphological properties of solid phase products [18, 45, 48], as well as the application of solid phase to selectively adsorb cellulose/hemicellulosederived reaction products such as carboxylic acids. In this context, this study aims to investigate the effect of temperature by hydrothermal processing of corn Stover with subcritical $\mathrm{H}_{2} \mathrm{O}$ on the morphology of solid products, and the application of chemically activated solid phase as adsorbent to investigate the capacity and/or efficiency to adsorb acetic acid from 1.0 to 4.0 $\mathrm{g} / \mathrm{L}$ model solutions at $25^{\circ} \mathrm{C}$.

\section{MATERIALS AND METHODS}

\subsection{Materials}

ATB-Bornin gently provided corn Stover used as renewable raw material.

\subsection{Pre-treatment of Corn Straw}

Corn Stover submitted to drying for 24 hours at 105 ${ }^{\circ} \mathrm{C}$ to remove moisture. Afterwards, the dried material was grinded using a cutting mill (Retsch, Germany, Model: SM 100). The particle size and geometry obtained by coupling a bottom sieve with square holes of $2.0 \mathrm{~mm}$.

\subsection{Elemental Analysis of Solid Phase}

The elemental chemical (Carbon, Hydrogen, Nitrogen, and Sulphur) analysis of solid phase products performed using an elemental analyzer (Elementar Analysensysteme $\mathrm{GmbH}$, Germany, Model: Vario EL III), and the procedures described elsewhere [34]. The oxygen content computed by difference using equation (1). The solid phase products were physicochemical characterized for dry matter (DM) and total organic content (TOC). The moist solid phase dried at $60^{\circ} \mathrm{C}$ for 24 hours (DM-60 ${ }^{\circ} \mathrm{C}$ ), followed by a second drying step at $105{ }^{\circ} \mathrm{C}$ for 24 hours $\left(\mathrm{DM}-105{ }^{\circ} \mathrm{C}\right)$. The dry matter content computed on basis the dry matter at $60{ }^{\circ} \mathrm{C}$, because of the high aqueous phase-to-solids ratio after hydrothermal experiments. The total organic content 
(TOC) determined by thermal treatment of dry matter $\left(\mathrm{DM}-105{ }^{\circ} \mathrm{C}\right)$ at $550{ }^{\circ} \mathrm{C}$ for 5 hours. The ash content computed by difference of dry matter at $105^{\circ} \mathrm{C}$ (DM$105{ }^{\circ} \mathrm{C}$ ) and total organic content (TOC) given by equation (2), as reported elsewhere [39].

$$
\begin{aligned}
& \mathrm{O}(\%)=100-\sum[\mathrm{C}+H+N+S+A s h] \\
& \mathrm{Ash}(\%)=\mathrm{DM}-105{ }^{\circ} \mathrm{C}-\text { TOC }
\end{aligned}
$$

\subsection{Solid Phase Characterization}

The characterization of solid phase products performed by scanning electron microscope (SEM), energy dispersive X-ray spectroscopy (EDX), and X-ray diffraction (XRD), being the equipment's and procedures described in details elsewhere [52-53].

\subsection{Chemical Analysis of Aqueous Phase}

\subsubsection{Physicochemical Analysis}

The aqueous phase was physicochemical characterized for $\mathrm{pH}$ and total carboxylic acids, expressed as total acetic acid content [34, 39].

\subsubsection{Chemical Analysis of Reaction Compounds}

GC and HPLC analysis identified and quantified selective cellulose/hemicellulose-derived compounds present in aqueous phase such as low-chain length carboxylic acids (acetic acid), and aldehydes (furfural and HMF). The equipment's specifications and procedures described in details elsewhere [34].

\subsection{Hydrothermal Processing of Corn Stover}

\subsubsection{Experimental Apparatus and Procedures}

The pilot scale cylindrical stirred tank stainless steel reactor of 5.0 gallon (Parr, USA, Model: 4555), with internal diameter of 9.5 in and 16.25 in height, weights $375 \mathrm{lbs}$. The reactor contains a mechanical agitation system with a stirrer motor of $3 / 4 \mathrm{hp}, 60 \mathrm{lbf}^{*}$ in Torque, and 02 impellers (ID $=5.25$ in) with 6-blades, a ceramic-3 zone heater of 4500 watts, a modular controller (Parr, USA, Model: 4848), 02 type J thermocouples inside a thermo well, operates at maximum 131 bar and $350{ }^{\circ} \mathrm{C}$. Initially, approximately $600 \mathrm{~g}$ of dried corn Stover weighed. Afterwards, $6000 \mathrm{~g}$ of fresh water introduced in the reactor. Then, the dried corn Stover soaked manually, and the compression bolts for flat gasket closed. By considering that bulk density of corn Stover for particles sizes of $0.8,1.6$ and $3.2 \mathrm{~cm}$ are $0.131,0.156$, and $0.158 \mathrm{~g} / \mathrm{cm}^{3}$, as reported elsewhere [54], and an average porosity of 0.770 confers a bed height of $8.54 \mathrm{~cm}$ of dried corn Stover. The operating temperature $\left(200,225\right.$, and $\left.250^{\circ} \mathrm{C}\right)$ set with a heating rate of $2.0^{\circ} \mathrm{C} / \mathrm{min}$. The reaction time computed from the time the reactor reaches the set point temperature $\left(\tau_{0}\right)$. Afterwards, the reactor is let to cool down until ambient temperature. The reaction products separated initially by using a manual mechanical press, producing a moist dewatered solid phase and a liquid phase, being the mass of liquid and moist solid phases determined gravimetrically. Then, the moist solid phase was submitted to drying at 105 ${ }^{\circ} \mathrm{C}$ for 24 hours, and the mass of dried solids and water determined gravimetrically. Samples of moist dewatered solids, liquid phase, and dried solid phase stored for physicochemical analysis and morphological characterization.

\subsubsection{Material Balances and Yields of Products by Hydrothermal Processing of Corn Stover}

Application of mass conservation principle in form of an overall steady state mass balance within the stirred tank sludge reactor, operating in batch mode, closed thermodynamic system, yields the following equations.

$$
\begin{aligned}
& \mathrm{M}_{\text {Reactor }}=\mathrm{M}_{\mathrm{Feed}}+\mathrm{M}_{\mathrm{H} 2 \mathrm{O}(\mathrm{S})} \\
& \mathrm{M}_{\text {Reactor }}=\mathrm{M}_{\mathrm{SP}}+\mathrm{M}_{\mathrm{LP}}+\mathrm{M}_{\mathrm{Gas}} \\
& \mathrm{M}_{\mathrm{LP}}=\mathrm{M}_{\mathrm{H} 2 \mathrm{O}(\mathrm{S})}+\mathrm{M}_{\mathrm{Hydrolisate}(\mathrm{R})}+\mathrm{M}_{\mathrm{H} 2 \mathrm{O}(\mathrm{R})}
\end{aligned}
$$

Where $\mathrm{M}_{\text {Feed }}=\mathrm{M}_{\text {Corn Stoverl }}$ is the mass of Corn Stover, $M_{\mathrm{H} 2 \mathrm{O}(\mathrm{S})}$ is the mass of solvent/diluent $\left(\mathrm{H}_{2} \mathrm{O}\right)$, $\mathrm{M}_{\mathrm{SP}}$ is the mass of solid phase (hydro-char), $\mathrm{M}_{\mathrm{Gas}}$ is the mass of gas, $M_{L P}$ is the mass of liquid phase, $M_{\text {Hydrolisates }(R)}$, is the mass of cellulose/hemicellulose and lignin-derived reaction products dissolved in the aqueous phase, $\mathrm{M}_{\mathrm{H} 2 \mathrm{O}(\mathrm{R})}$, is the mass of $\mathrm{H}_{2} \mathrm{O}$ produced during the course of reaction. The process performance evaluated by computing the yields of solid and liquid reaction products defined by equations (6) and (7).

$$
\begin{aligned}
& \operatorname{Yield}_{\mathrm{SP}}(\%)=\frac{\mathrm{M}_{\mathrm{SP}}}{\mathrm{M}_{\text {Corm Stover }}} \times 100 \\
& \operatorname{Yield}_{\mathrm{LP}}(\%)=\frac{\left(\mathrm{M}_{\mathrm{LP}}-M_{H 2 \check{O}(S)}\right)}{\mathrm{M}_{\text {Cor Stover }}} \times 100
\end{aligned}
$$

Where Yield $_{\mathrm{SP}}$, is the yield of solid phase, and Yield $_{\mathrm{LP}}$, is the yield of liquid phase. 


\subsection{Adsorption of $\mathrm{C}_{2} \mathrm{H}_{4} \mathrm{O}_{2}$ on the Solid Phase}

\subsubsection{Experimental Apparatus and Procedures}

The solid phase product obtained by hydrothermal processing of corn Stover at $250{ }^{\circ} \mathrm{C}$, reaction time of 240 minutes, and biomass-to-water ratio of 1:10, was activated chemically with a $2.0 \mathrm{M}$ sodium hydroxide solution under agitation for 4 hours. Afterwards, the solid phase washed with fresh water 03 times and dried at $105{ }^{\circ} \mathrm{C}$ for 24 hours. The acetic acid solutions (1.0, 2.0 , and $4.0 \mathrm{mg} / \mathrm{mL}$ ) prepared by dilution of acetic acid in $10 \mathrm{ml}$ distilled and deionized water. The adsorption experiments were carried out with $0.1 \mathrm{~g}$ of activated solid phase and $10 \mathrm{~mL}$ acetic acid solutions at 1.0 atmosphere and $25{ }^{\circ} \mathrm{C}$ using an orbital shaker (Quimis, Brazil, Model: Q225M22). The chemically activated solid phase introduced inside a borosilicate glass Erlenmeyer of $50 \mathrm{~mL}$ and completed with $10 \mathrm{~mL}$ acetic acid solution. Because adsorption of acetic acid into the chemically activated solid phase is very fast, as observed by pre-tests experiments, the adsorption kinetics was investigated at $30,60,120,240,480$, and 600 seconds. The Erlenmeyer flasks (06), one for each time withdraw, inserted in the orbital shaker. Samples of $2.0 \mathrm{~mL}$ were withdraw, followed by filtration to separate the solid particles and the liquid phase (filtrate). Afterwards, the acid value of filtrate determined by AOCS Cd 3d-63 method [53]. For the adsorption isotherm determination, acetic acid models solutions of $0.5,0.25,0.1,0.05,0.02$, and $0.01 \mathrm{M}$ were prepared and made in contact to approximately $0.1 \mathrm{~g}$ of adsorbent until equilibrium is achieved. Afterwards, the mass of acetic acid consumed and the equilibrium concentration determined by titration.

\subsubsection{Adsorption Kinetics and Isotherm Models}

The solid phase obtained by $\mathrm{HTC}$ at $250{ }^{\circ} \mathrm{C}, 240$ minutes, and biomass-to-water 1:10, chemically activated with a $2.0 \mathrm{M}$ sodium hydroxide solution, was applied as adsorbent to investigate the capacity and/or efficiency to adsorb acetic acid from 1.0, 2.0 and 4.0 $\mathrm{g} / \mathrm{L}$ model solutions at $25^{\circ} \mathrm{C}$. Since the acid value is directly proportional to the concentration of acetic acid $C_{A C}$ in aqueous solution, expressed by equation (8), a dimensionless concentration is defined by equation (9), where $I_{(0)}$, is the solution initial acid value, $I_{(\tau)}$, the solution acid value at time $(\tau), I_{(\infty)}=I^{*}$, the solution acid value at $(\infty)$, that is the solution acid value at equilibrium. When the concentration of acetic acid in aqueous solution, measured indirectly by the acid value, reaches equilibrium, the dimensionless concentration tends to 1.0. Equilibrium data of acetic acid adsorption on chemically activated solid phase was analyzed by using a Langmuir isotherm, defined by equation (11), where $X_{\mathrm{CH} 3 \mathrm{COOH}, \mathrm{Ads}}^{*}$ is the equilibrium adsorption capacity of acetic acid in adsorbent, $C_{\mathrm{CH} 3 \mathrm{COOH}}^{*}$, the equilibrium concentration of acetic acid in aqueous solution, $K_{0}, X_{\text {Max }}$, adsorption constants associated to free energy adsorption and maximum adsorption capacity, and $\mathrm{n}$ an exponent.

$$
\begin{aligned}
& I \propto C_{A C}, I=K C_{A C} \\
& I=\frac{\left[I_{(0)}-I_{(\tau)}\right]}{\left[I_{(0)}-I_{(\infty)}\right]}=\frac{\left[C_{A C(0)}-C_{A C(\tau)}\right]}{\left[C_{A C(0)}-C_{A C(\infty)}\right]} \\
& I_{(\infty)}=I^{*}, C_{A C(\infty)}=C_{A C}{ }^{*} \\
& X_{C H 3 С O O H, A d s}^{*}=\frac{K_{0} * X_{M a x} *\left(C_{C H 3 \mathrm{COOH}}^{*}\right)^{n}}{\left[1+K_{0} *\left(C_{C H 3 \mathrm{COOH}}^{*}\right)^{n}\right]}
\end{aligned}
$$

The kinetic of adsorption process assumed to be described by a first order kinetic, expressed in terms of a dimensionless concentration given by equation (12).

$$
\mathrm{I}=\mathrm{A} *\left[1-\exp \left(-\mathrm{K}^{*} \tau\right)\right]
$$

Where $\mathrm{A}$, is a dimensionless constant, associated to the acid value at equilibrium $I_{(\infty)}=I^{*}$, and $\mathrm{K}$, the adsorption kinetic constant.

\section{RESULTS AND DISCUSSIONS}

\subsection{Hydrothermal Processing of Corn Stover}

\subsubsection{Process Conditions and Material Balances}

The process conditions, material balances, and yields of reaction products (solid, and liquid) are illustrated in Table 1 and Figure 1. The experimental data shows solid phase yields ranging from 62.92 to $35.82 \%$ (wt.), and liquid phase yields between 35.43 and $54.59 \%$ (wt.). The solid phase yield decreases along with the temperature in a sigmoid fashion, while that of liquid phase yield increases in the same fashion, showing an inflection region between 200 and $225^{\circ} \mathrm{C}$, whereas a drastic change on both solid and liquid phase yields takes place. This behavior is according to the statement of Möller et al. [32], who stated that at temperatures below $200{ }^{\circ} \mathrm{C}$, the main reaction products is a solid, while between 200 and $350{ }^{\circ} \mathrm{C}$, liquid products dominates. A drastic change on the reaction products yields, occurred between 200 and $225{ }^{\circ} \mathrm{C}$, 
Table 1: Process parameters and overall steady state material balances by HTC of corn Stover with at 200, 225, and $250^{\circ} \mathrm{C}, 240$ minutes reaction time, and biomass-to-water ratio of 1:10, using a pilot scale STR of 5.0 gallon.

\begin{tabular}{|c|c|c|c|}
\hline \multirow[t]{2}{*}{ Process Parameters } & \multicolumn{3}{|c|}{$\begin{array}{c}\text { Temperature } \\
{\left[{ }^{\circ} \mathrm{C}\right]}\end{array}$} \\
\hline & 200 & 225 & 250 \\
\hline Mass of Corn Sover [g] & 600.12 & 600.08 & 600.10 \\
\hline Mass of $\mathrm{H}_{2} \mathrm{O}[\mathrm{g}]$ & 6002.10 & 6000.50 & 6000.70 \\
\hline Mechanical Stirrer Speed [rpm] & 90 & 90 & 90 \\
\hline Initial Temperature $\left[{ }^{\circ} \mathrm{C}\right]$ & 30 & 30 & 30 \\
\hline Heating Rate $\left[{ }^{\circ} \mathrm{C} / \mathrm{min}\right]$ & 2 & 2 & 2 \\
\hline Process Time [min] & 240 & 240 & 240 \\
\hline Mas of Aqueous Phase [g] & 6239.36 & 6314.77 & 6328.31 \\
\hline Mass of Biochar [g] & 344.44 & 247.27 & 214.99 \\
\hline Mass of Liquid [g] & 237.26 & 314.17 & 327.61 \\
\hline Yield of Biochar [wt.\%] & 57.39 & 41.20 & 35.82 \\
\hline Yield of Liquid [wt.\%] & 39.53 & 52.35 & 54.59 \\
\hline
\end{tabular}

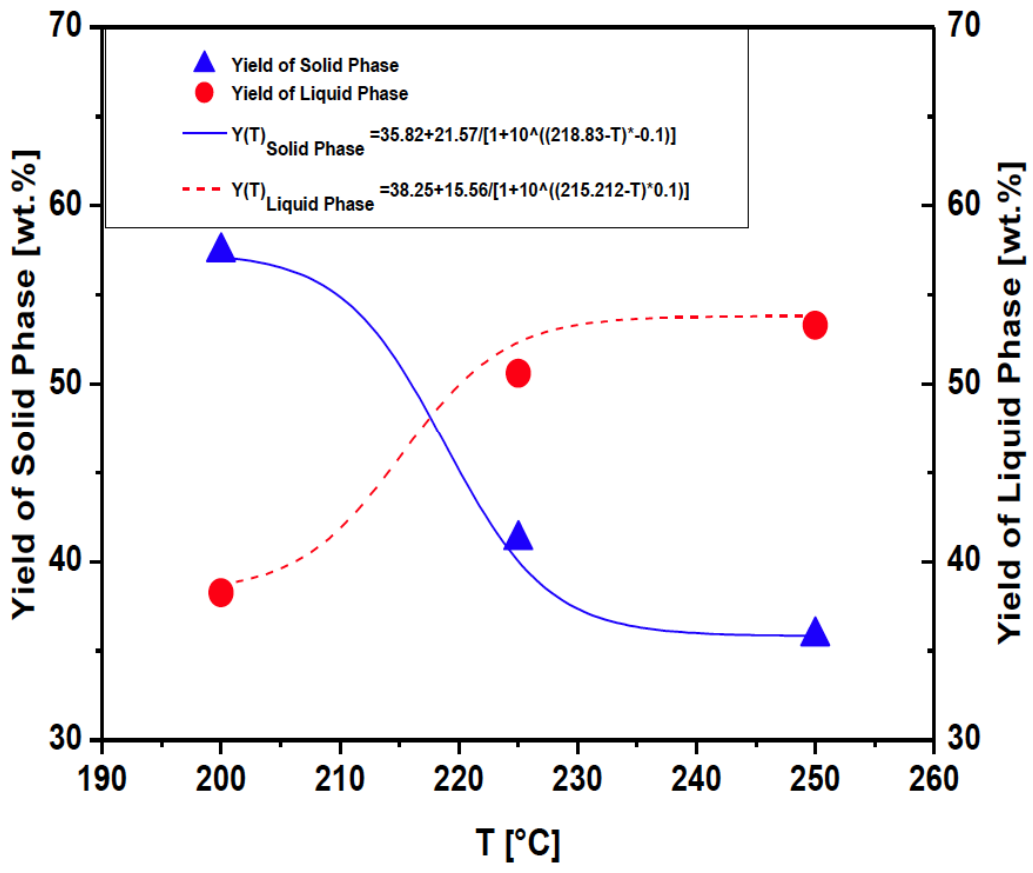

Figure 1: Yield of reaction products (solid and liquid phases) obtained by HTC of corn Stover at 200, 225, and $250{ }^{\circ} \mathrm{C}, 240$ minutes reaction time, and biomass-to-water ratio of 1:10, in a pilot scale STR of 5.0 gallon.

showing that hydrothermal carbonization occurred between 200 and $225{ }^{\circ} \mathrm{C}$, while hydrothermal liquefaction dominates between 225 and $250{ }^{\circ} \mathrm{C}$. As corn Stover consists by cellulose (34.5-41.3\%), hemicellulose (27.7-28.1\%), lignin (17.8-22.1\%), and ash (5.6-7.8\%) [19, 55-56], and according to the literature [20, 45, 47-49], hot compressed water in the subcritical state dissolves soluble substances in biomass and decomposes hemicellulose into sugar monomers, the results obtained for solid phase yields are according to similar data reported in the literature [18-20, 45-46].

\subsubsection{Elemental Analysis of Solid Phase}

Table 2 presents the physicochemical and elemental analysis of solid phase products after HTC of corn Stover at 200,225 , and $250{ }^{\circ} \mathrm{C}, 240$ minutes reaction time, and biomass-to-water ratio of 1:10 in a pilot scale STR, related to dry matter. The results show 
Table 2: Elemental characterization of solid phase products obtained by HTC of corn Stover at 200,225 , and $250{ }^{\circ} \mathrm{C}$, 240 minutes reaction time, biomass-to-water ratio of 1:10, using a pilot scale STR of 5.0 gallon.

\begin{tabular}{|c|c|c|c|}
\hline \multirow{2}{*}{ Elemental Characterization } & \multicolumn{3}{|c|}{ Solid Phase } \\
\cline { 2 - 4 } & \multicolumn{3}{|c|}{ Temperature [ ${ }^{\circ} \mathbf{C}$ ] } \\
\cline { 2 - 4 } & $\mathbf{2 0 0}$ & $\mathbf{2 2 5}$ & $\mathbf{2 5 0}$ \\
\hline \hline Ash [\%] & 11.9 & 10.07 & $9.26^{*}$ \\
\hline $\mathrm{N}[\%]$ & 0.630 & 0.736 & 59.17 \\
\hline $\mathrm{C}[\%]$ & 51.19 & 56.73 & 0.2353 \\
\hline $\mathrm{S}[\%]$ & 0.3133 & 0.2147 & 5.719 \\
\hline $\mathrm{H}[\%]$ & 6.655 & 6.500 & 24.75 \\
\hline $\mathrm{O}[\%]$ & 29.31 & 25.75 & 24.57 \\
\hline $\mathrm{HHV}^{* *}[\mathrm{MJ} / \mathrm{kg}]$ & 22.39 & & 24.53 \\
\hline
\end{tabular}

*Results computed by statistical analysis.

that carbon content varied between 51.19 and $59.07 \%$ (wt.), oxygen between 29.31 and $24.75 \%$ (wt.), hydrogen between 6.655 and $5.719 \%$ (wt.), and nitrogen between 0.630 and $0.861 \%$ (wt.), showing an increase of carbon and nitrogen contents in the solid products, as well as a decrease on the oxygen and hydrogen contents. The carbon contents are higher, and the oxygen content lower, while the hydrogen contents are close compared to similar data reported in the literature [16-18].

The experimental data illustrated in Figure 2 shows that nitrogen increases and the hydrogen decreases in a linear smooth fashion, while carbon increases and oxygen decreases along with the temperature in a sigmoid fashion, showing an inflection region between 200 and $225{ }^{\circ} \mathrm{C}$, whereas a change on both carbon and oxygen contents in solid phase takes place. This behavior is similar to that observed for the solid and liquid phase yields, as described in Section 3.1.1, showing that temperature acts to produce a rich carbonaceous energy material.

\subsection{Characterizationof Solid Phase}

\subsubsection{SEM Analysis of Solid Phase}

The scanning electron microscopies of solid phase products after HTC of corn Stover with subcritical $\mathrm{H}_{2} \mathrm{O}$

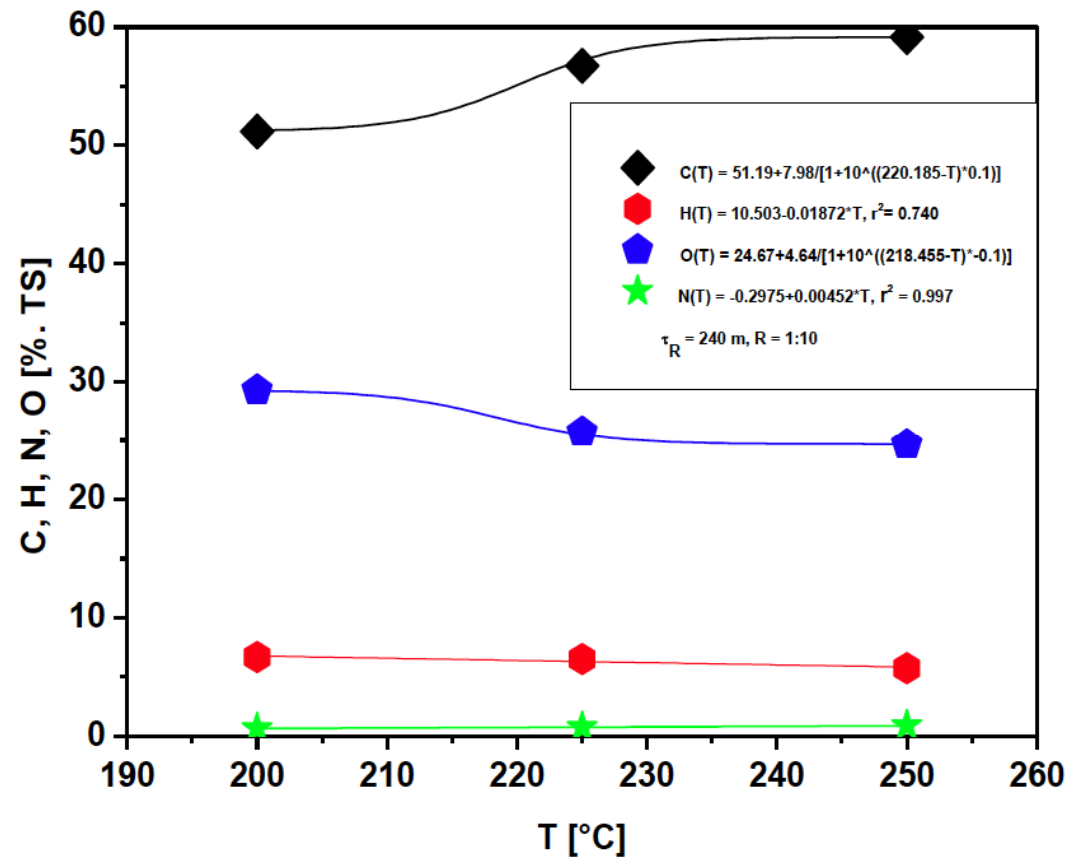

Figure 2: Elemental analysis of solid phase products $(\mathrm{C}, \mathrm{H}, \mathrm{N}, \mathrm{S})$ after HTC of corn Stover at 200,225 , and $250{ }^{\circ} \mathrm{C}, 240$ minutes reaction time, and biomass-to-water ratio of $1: 10$, in a pilot scale STR of 5.0 gallon. 
at 200,225 , and $250{ }^{\circ} \mathrm{C}, 240$ minutes reaction time, and biomass-to-water ratio of 1:10, in a pilot scale STR, illustrated in Figure 3. SEM was applied to investigate changes on the vegetal surface structure along with temperature. The SEM images indicate that disaggregate, amorphous and heterogeneous structures with irregular shapes dominates, being similar for the hydrothermal processing at 200 and 225 ${ }^{\circ} \mathrm{C}$, showing the temperature had little effect on the vegetal morphology, as the vegetal structure largely retains the original microscopic characteristics. On the other hand, for hydrothermal processing at $250{ }^{\circ} \mathrm{C}$, it can be seen an aggregate amorphous solid phase with only small traces and/or characteristics of original vegetal surface structure, being the carbonization grade higher, showing that temperature has caused substantial changes on the morphological structure of corn Stover by destructing and/or degrading the plant cell walls [59]. The results are according to similar studies on the effect of temperature on the surface and morphology of biochar and hydro-char [18, 57-59].

\subsubsection{EXD Analysis of Solid Phase}

Table 3 illustrates the energy dispersive X-ray spectroscopy of solid phase products at the points marked by EDX technique. Each solid phase sample was analyzed in 05 (five) different points marked by EDX. The results show that carbon content increases,

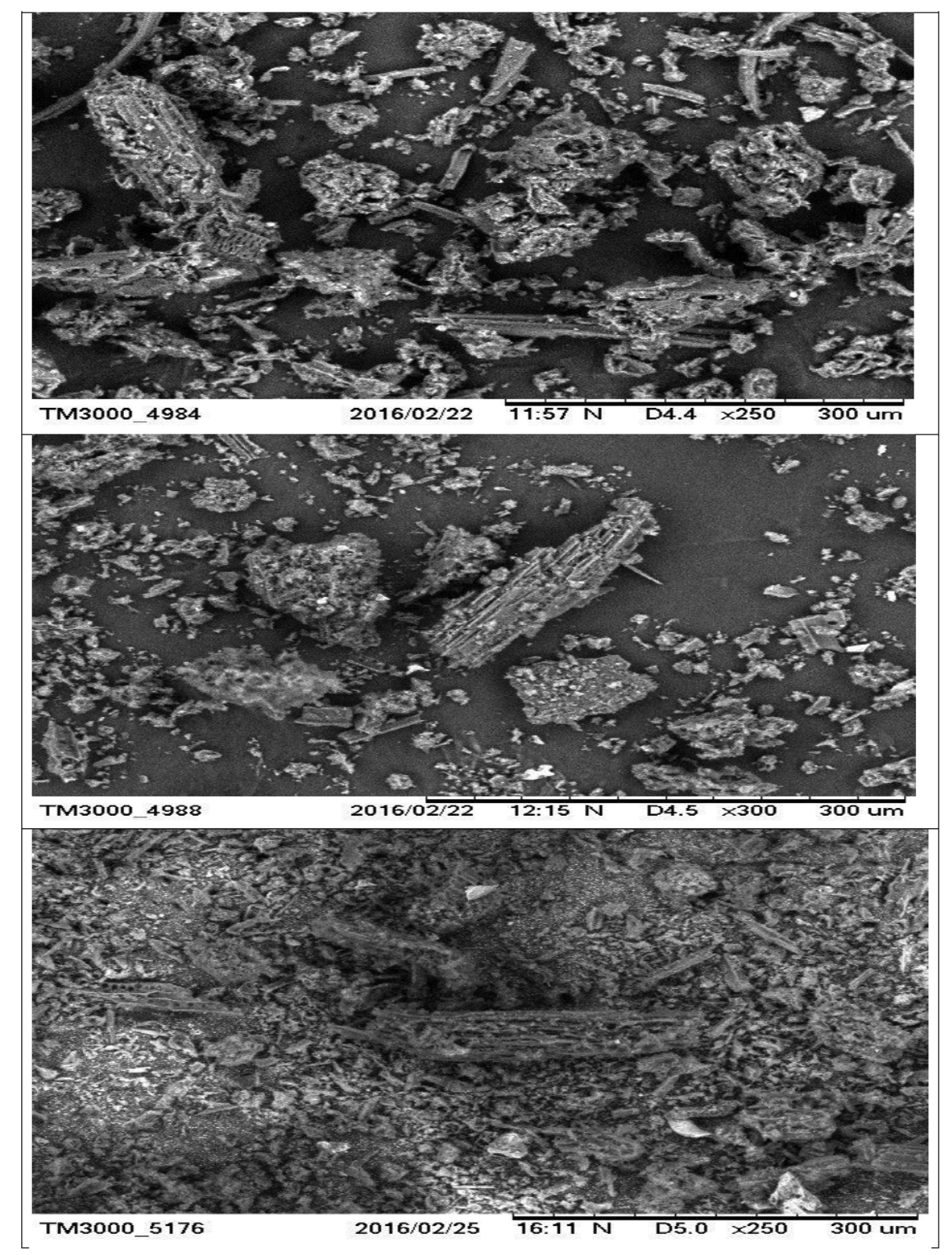

Figure 3: SEM of solid phase products obtained by HTC of corn Stover at $200{ }^{\circ} \mathrm{C}\left(\mathrm{TM} 3000 \_4984\right), 225^{\circ} \mathrm{C}\left(\mathrm{TM} 3000 \_4988\right)$, and $250{ }^{\circ} \mathrm{C}$ (TM3000_5176), 240 minutes reaction time, and biomass-to-water ratio of 1:10, in a pilot scale STR of 5.0 gallon. 
Table 3: Percentages in mass and atomic mass of solid phase products, obtained by HTC of corn Stover at 200, 225, and $250^{\circ} \mathrm{C}, 240$ minutes reaction time, biomass-to-water ratio of 1:10, using a pilot scale STR of 5.0 gallon, at the point marked by EDX technique.

\begin{tabular}{|c|c|c|c|c|c|c|c|c|c|}
\hline \multirow[b]{3}{*}{$\begin{array}{l}\text { Chemical } \\
\text { Elements }\end{array}$} & \multicolumn{9}{|c|}{ Solid Phase Products } \\
\hline & \multicolumn{3}{|c|}{$200^{\circ} \mathrm{C}$} & \multicolumn{3}{|c|}{$225^{\circ} \mathrm{C}$} & \multicolumn{3}{|c|}{$250^{\circ} \mathrm{C}$} \\
\hline & $\begin{array}{l}\text { Mass } \\
\text { [wt.\%] }\end{array}$ & $\begin{array}{c}\text { Atomic Mass } \\
\text { [wt.\%] }\end{array}$ & SD & $\begin{array}{l}\text { Mass } \\
\text { [wt.\%] }\end{array}$ & $\begin{array}{c}\text { Atomic Mass } \\
\text { [wt.\%] }\end{array}$ & SD & $\begin{array}{l}\text { Mass } \\
{[w t . \%]}\end{array}$ & $\begin{array}{c}\text { Atomic Mass } \\
\text { [wt.\%] }\end{array}$ & SD \\
\hline C & 71.980 & 77.437 & 0.818 & 73.890 & 79.177 & 0.654 & 76.042 & 81.051 & 0.631 \\
\hline $\mathrm{O}$ & 27.836 & 22.474 & 0.819 & 25.736 & 20.703 & 0.656 & 23.591 & 18.877 & 0.632 \\
\hline $\mathrm{Si}$ & 0.194 & 0.089 & 0.043 & - & - & - & - & - & - \\
\hline $\mathrm{Ca}$ & - & - & - & 0.374 & 0.120 & 0.032 & - & - & - \\
\hline $\mathrm{Zn}$ & - & - & - & & & & 0.366 & 0.072 & 0.065 \\
\hline
\end{tabular}

$\mathrm{SD}=$ Standard Deviation .

while that of oxygen decreases along with the process temperature, being the measured carbon contents higher and the oxygen contents close to those described in Table 2. This is due to limitations of elemental analysis by EDX technique, which is not able to identify chemical elements like hydrogen and nitrogen. In addition, the computation of carbon and oxygen contents described in Table 2 is performed by subtracting the ash content, as described in equation (1). The EDX identified also the presence of $\mathrm{K}, \mathrm{Na}$, and $\mathrm{P}$, as well as $\mathrm{Si}$ in almost all the points marked by EDX, being the Si content in some points around 10\% [wt.] at 200 and $225{ }^{\circ} \mathrm{C}$. The inorganics compounds identified by EDX present in the solid phase products are according to inorganic compounds identified in corn Stover after drying at $105^{\circ} \mathrm{C}$ [60].

\subsubsection{XRD Analysis of Solid Phase}

Figure 4 shows the XRD analysis of solid phase products obtained by HTC of corn Stover at 200, 225, and $250{ }^{\circ} \mathrm{C}$. At $200{ }^{\circ} \mathrm{C}$, the results identified the presence of three (03) crystalline phases: 1 - $\alpha$-Quartz $\left(\mathrm{SiO}_{2}\right)$ with a peak of higher intensity $(100 \%)$ on the position 20: 20.68 (ICDD:01-089-8940); 2 - $\alpha$ Cristobalite $\left(\mathrm{SiO}_{2}\right)$ with peaks of high intensity on the positions 20: 15.53 (79\%) and 21.96 (90.07\%) (ICDD: 01-077-1316); 3 - Graphite (C) with a peak of medium intensity (59.38\%) on the position 20: 26.45 (ICDD: 01012-0212). At $225{ }^{\circ} \mathrm{C}$, the results identified the presence of three (03) crystalline phases: 1 - Graphite (C) with a peak of medium intensity $(53.75 \%)$ on the position 29: 26.57 (ICDD: 00-025-0284); 2 - Cristobalite $\left(\mathrm{SiO}_{2}\right)$ with peaks of high and low intensity on the positions 20: 22.47 (100\%) and 49.94 (49.86\%) (ICDD:01-082-1235); 3 - Quartz $\left(\mathrm{SiO}_{2}\right)$ with a peaks of medium and low intensity on the positions 20: 20.73 (65.99\%) and 49.94 (49.86\%) (ICDD: 01-089-1961). At
$250{ }^{\circ} \mathrm{C}$, the results confirm the presence of three (03) crystalline phases: 1 - Graphite (C) with a peak of high intensity (100\%) on the position 20: 26.52 (ICDD: 00025-0284); $2-\alpha$-Cristobalite $\left(\mathrm{SiO}_{2}\right)$ with peaks of medium intensity on the positions 20: 15.07 (71.53\%) (ICDD: 01-077-1316); 3- $\alpha$-Quartz $\left(\mathrm{SiO}_{2}\right)$ with a peak of high intensityon the position 20: 20.40 (90.30\%) (ICDD: 01-089-8940). The XRD results identified the occurrence of peaks of higher intensity of Graphite (C) along with the temperature, as well as a diminution of peaks intensity for $\alpha$-Cristobalite $\left(\mathrm{SiO}_{2}\right)$ and $\alpha$-Quartz $\left(\mathrm{SiO}_{2}\right)$, showing that higher temperatures favors the formation of mineralogical phase Graphite (C). This is according to the results described in Section 3.2.2, being identified the presence of $\mathrm{Si}$ in almost all the points marked by EDX, as well as an increase on carbon content with the temperature.

\subsection{HHV and van Krevelan Diagram of Solid Phase}

Figure 5 illustrates the hydrogen-to-carbon ratio $(\mathrm{H} / \mathrm{C})$ as a function of oxygen-to-carbon ratio $(\mathrm{O} / \mathrm{C})$, as well as the high heating value (HHV) of corn Stover at $105^{\circ} \mathrm{C}[18,59]$, and after HTC at 200, 225, and 250 ${ }^{\circ} \mathrm{C}, 240$ minutes reaction time, biomass-to-water ratio of $1: 10$, in a pilot scale STR of 5.0 gallon. The results show that $\mathrm{H} / \mathrm{C}$ ranged between 0.84 and 0.31 , and $\mathrm{O} / \mathrm{C}$ between 1.62 and 1.16. In addition, $\mathrm{H} / \mathrm{C}$ decreases exponentially with decreasing $\mathrm{O} / \mathrm{H}$, that is with increasing temperature, if one takes into account the $\mathrm{H} / \mathrm{C}$ and $\mathrm{O} / \mathrm{C}$ values of corn Stover after drying at 105 ${ }^{\circ} \mathrm{C}$. This suggests a growing aromaticity of solid phase products along with the temperature, being the results according to similar studies reported in the literature [18, 19, 59, 61], particularly that of Mumme et al. [61]. Mumme et al. reported $\mathrm{H} / \mathrm{C}$ values between 1.35 and 1.16 by HTC of digestate maize silage at 190,230 , and $270{ }^{\circ} \mathrm{C}$, for reaction time of 360 minutes. 

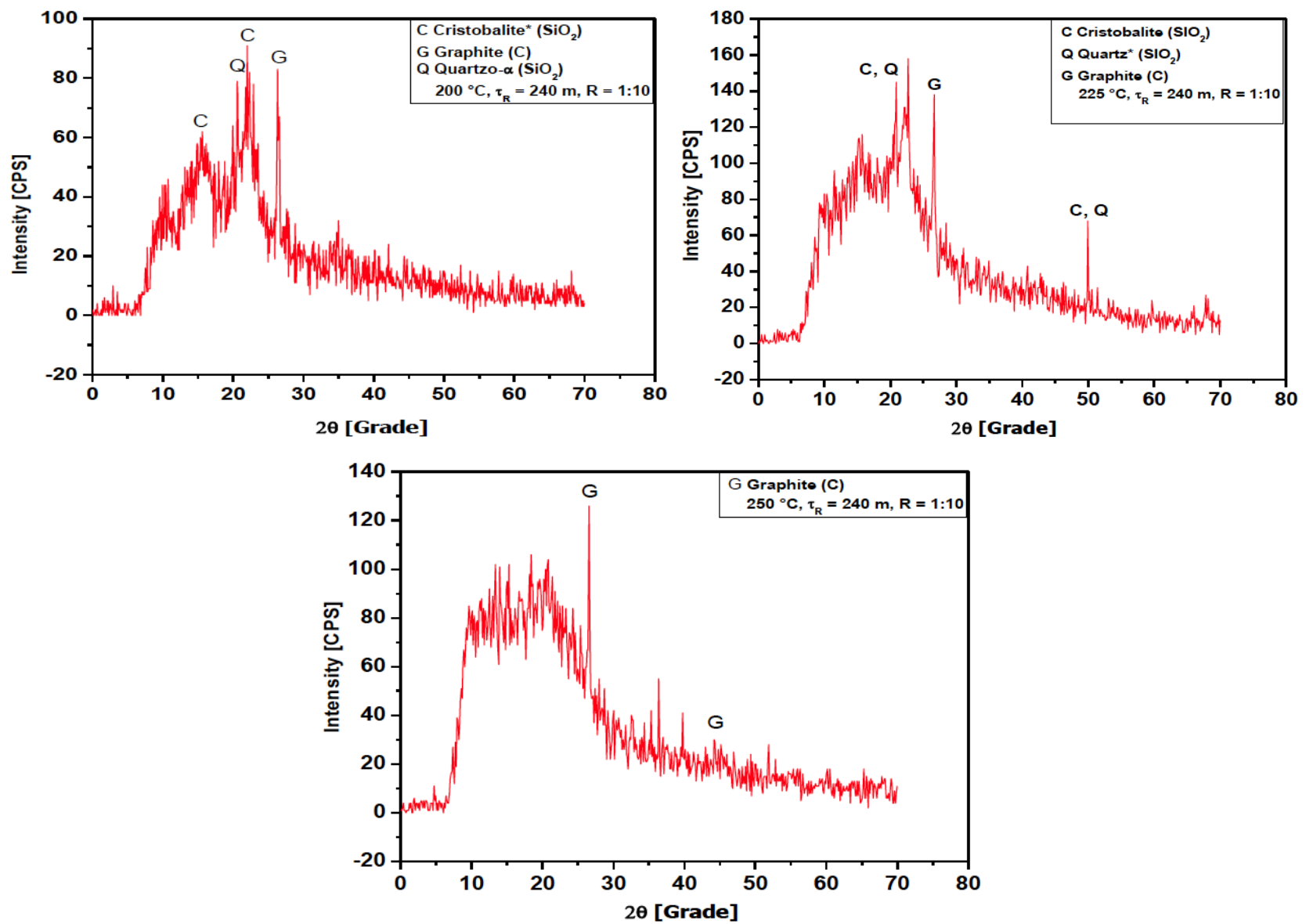

Figure 4: XRD of solid phase products obtained by HTC of corn Stover at 200,225 , and $250{ }^{\circ} \mathrm{C}, 240$ minutes reaction time, and biomass-to-water ratio of 1:10, in a pilot scale STR of 5.0 gallon.
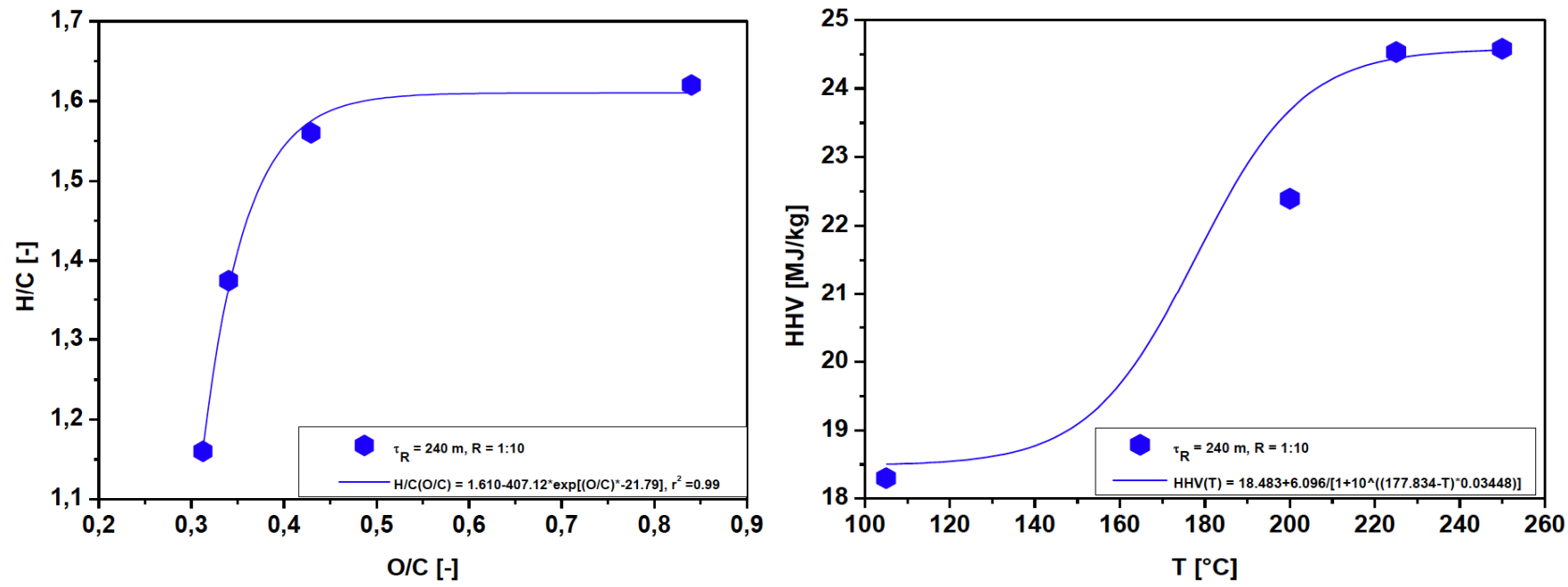

Figure 5: $\mathrm{H} / \mathrm{C}$ as a function of $\mathrm{O} / \mathrm{C}$ and high heating value (HHV) of corn Stover at $105^{\circ} \mathrm{C}$ and after $\mathrm{HTC}$ at 200,225 , and 250 ${ }^{\circ} \mathrm{C}, 240$ minutes reaction time, biomass-to-water ratio of $1: 10$, in a pilot scale STR of 5.0 gallon.

The high heating values (HHV) of corn Stover at $105^{\circ} \mathrm{C}$ and after $\mathrm{HTC}$ at 200,225 , and $250{ }^{\circ} \mathrm{C}$ ranged between 18.30 and $24.58 \mathrm{MJ} / \mathrm{kg}$, showing a densification of energy material of approximately $34.32 \%$. In addition, HHV of solid phase products increases, in a sigmoid fashion, along with the temperature, showing an inflection point between 200 and $225{ }^{\circ} \mathrm{C}$, as observed in section 3.1.1. In fact, by increasing the temperature from 225 to $250{ }^{\circ} \mathrm{C}$, an increase of only $0.19 \%$ occurs on the densification of 
energy material, indicating that process has reached its maximal densification state. The results are lower compared to that reported by Mumme et al. [61], but very close to those of Reza et al. [62], who reported $\mathrm{HHV}$ values between 20.30 and $24.50 \mathrm{MJ} / \mathrm{kg}$ at 200 , 230 , and $260{ }^{\circ} \mathrm{C}$ for loblolly pine, a raw material containing $11.9,54.0$, and $25.0 \%$ (wt.), lignin, cellulose, and hemicellulose, respectively.

\subsection{Chemical Analysis of Aqueous Compounds}

During the hydrothermal processing of lignincellulose rich biomass, a series of chemical reactions takes place, including hydrolysis, dehydration, decarboxylation, polymerization, aromatization, among others [32, 63], producing lignin and cellulose-derived compounds such as sugars, carboxylic acids, aldehydes, phenols, etc. [19, 20, 34-36, 59, 61-62]. The presence of cellulose-derived toxic compounds in the aqueous phase of hydrothermal processing of biomass makes it necessary a new pretreatment step for wastewater process streams, prior to reuse and/or discharge [34]. In this context, selective cellulose/hemicellulose-derived compounds such as acetic acid, and aldehydes (furfural, HMF) chemically identified and analyzed, and the results illustrated in Table 4 and Figure 6 . The results show that acetic acid concentrations and total carboxylic acids concentrations, expressed as total acetic acid, varied between 4020 and 5040 and 4064 and $5387 \mathrm{mg} / \mathrm{L}$, respectively, showing an exponential increase along with the temperature. Reza et al. [39], reported an increase of acetic acid concentration along with temperature, remaining the concentration of acetic acid almost stable for long reaction times. HMF and furfural concentrations decrease sharply with increasing temperature, being not detectable at $250{ }^{\circ} \mathrm{C}$. This behavior was also observed by Reza et al. [39], reporting for cellulose hydrothermal treatment at 260 ${ }^{\circ} \mathrm{C}$, that HMF degrades rapidly during the reaction, being not detectable after 60 minutes. A similar behavior was found for furfural concentrations in process water-streams by HTC of wheat straw and poplar [39], as well as pine wood and Massaranduba [34], whereas an increase on process temperature after $250{ }^{\circ} \mathrm{C}$ and 240 minutes reaction time leads to a significant decrease on furfural concentration [34, 39]. In addition, the concentrations of acetic acid, HMF and furfural are according to similar data [34, 39]. The $\mathrm{pH}$ varied between 3.77 and 3.91 , showing that acetic acid, but not only, has a great effect on the acidity of process water-streams by hydrothermal processing of biomass.

\subsection{Adsorption Kinetics and Isotherm Models}

As reported elsewhere [34], one of the major drawbacks of hydrothermal processing of biomass is the presence of cellulose and lignin-derived toxic and hazardous substances such as furfural, hydroxymethylfurfural, and phenols in process waterstreams, as well as its high acidity, conferred by the

Table 4: Concentration of aldehydes ( $\mathrm{HMF}$, furfural), acetic acid $\left(\mathrm{C}_{2} \mathrm{H}_{4} \mathrm{O}_{2}\right)$, total acetic acid $\left(\mathrm{C}_{2} \mathrm{H}_{4} \mathrm{O}_{2}+\mathrm{C}_{3} \mathrm{H}_{6} \mathrm{O}_{2}+\mathrm{C}_{4} \mathrm{H}_{8} \mathrm{O}_{2}+\right.$ $\mathrm{C}_{5} \mathrm{H}_{10} \mathrm{O}_{2}+\mathrm{C}_{6} \mathrm{H}_{12} \mathrm{O}_{2}$ ) in the aqueous phase at $25^{\circ} \mathrm{C}$ and $1.0 \mathrm{~atm}$ after $\mathrm{HTC}$ of corn Stover at 200, 225, and $250{ }^{\circ} \mathrm{C}$, 240 minutes reaction time, biomass to-water ratio of $1: 10$, using a pilot scale STR of 5.0 gallon

\begin{tabular}{|c|c|c|c|}
\hline \multirow{2}{*}{ Concentration aldehydes [mg/L] } & \multicolumn{3}{|c|}{ Temperature $\left[{ }^{\circ} \mathrm{C}\right]$} \\
\hline & 200 & 225 & 250 \\
\hline HMF: CAS: $67-47-0$ & 443.9 & 170.4 & 0.0 \\
\hline Furfural: CAS:98-01-1 & 686.7 & 22.81 & 0.0 \\
\hline Concentration of carboxylic acids [mg/L] & & & \\
\hline $\begin{array}{l}\text { Acetic acid: CAS: 64-19-7 } \\
\text { O }\end{array}$ & 4020 & 4360 & 5040 \\
\hline $\begin{array}{c}\text { Total acetic acid } \\
\left(\mathrm{C}_{2} \mathrm{H}_{4} \mathrm{O}_{2}+\mathrm{C}_{3} \mathrm{H}_{6} \mathrm{O}_{2}+\mathrm{C}_{4} \mathrm{H}_{8} \mathrm{O}_{2}, \mathrm{C}_{5} \mathrm{H}_{10} \mathrm{O}_{2}+\mathrm{C}_{6} \mathrm{H}_{12} \mathrm{O}_{2}\right)\end{array}$ & 4064 & 4619 & 5387 \\
\hline $\mathrm{pH}$ & 3.77 & 3.91 & 3.83 \\
\hline
\end{tabular}



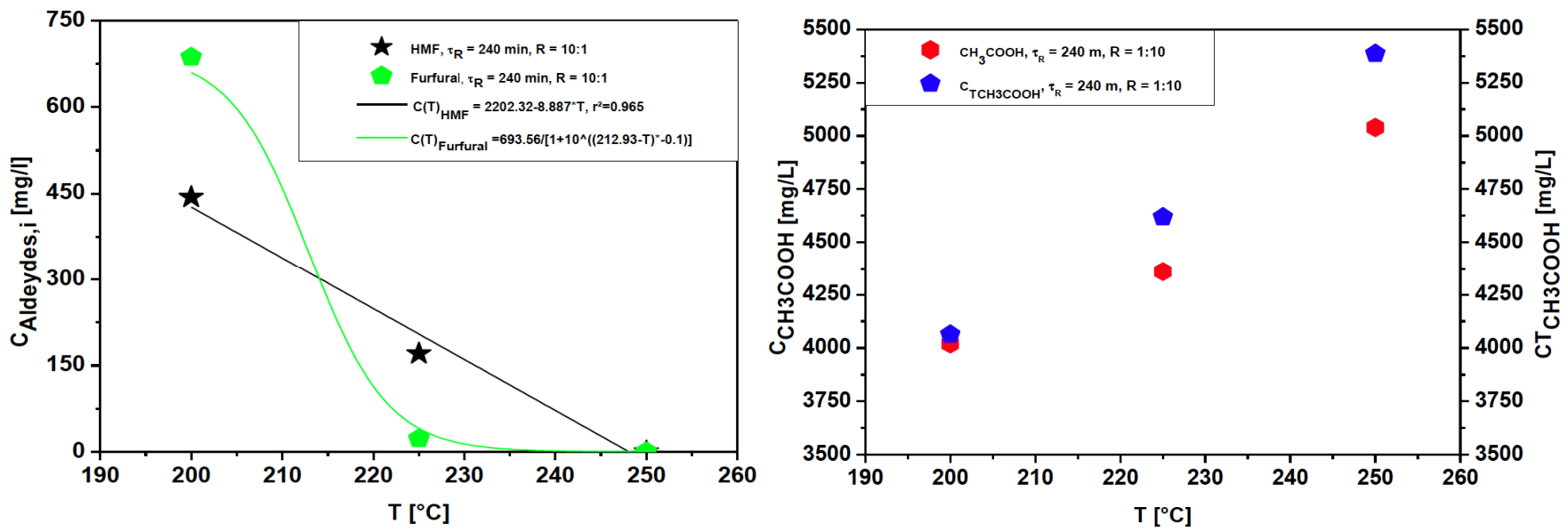

Figure 6: Concentration of $\mathrm{HMF}$, furfural, acetic acid, and total acetic acid in the aqueous phase at $25^{\circ} \mathrm{C}$ and 1.0 atm. after $\mathrm{HTC}$ of corn Stover at 200,225 , and $250{ }^{\circ} \mathrm{C}, 240$ minutes reaction time, biomass-to-water ratio of $1: 10$, using a pilot scale STR of 5.0 gallon.

presence of carboxylic acids such as acetic acid [3440]. In this context, the chemically activated solid phase obtained by $\mathrm{HTC}$ of corn Stover at $250{ }^{\circ} \mathrm{C}, 240$ minutes, biomass-to-water ratio of 1:10, was applied as adsorbent to investigate the capacity and/or efficiency to adsorb acetic acid, the major carboxylic acid present in HTC process water-streams, from 1.0, 2.0 and 4.0 $\mathrm{g} / \mathrm{L}$ model solutions at $25{ }^{\circ} \mathrm{C}$. Figure 7 illustrates the adsorption kinetics and isotherm of acetic acid solutions on the activated solid phase. The kinetic of acetic acid adsorption on the chemically activated solid phase is fast, being the equilibrium reached in approximately 240 seconds, for all the model solutions. This is probably due to the chemical modification of adsorption surface and internal porous, micro-porous, and macro-porous by sodium hydroxide, being the acid molecules dissociated in water captured by the charged active sites. In addition, the first order kinetic model correlates well the experimental data, showing correlation coefficients $\left(r^{2}\right)$ between 0.949 and 0.993 . The adsorption isotherm of Langmuir correlates well the adsorption equilibrium, being the regression coefficient $\left(r^{2}\right) 0.994$. The maximum adsorbent capacity was approximately $650 \mathrm{mg} / \mathrm{g}$, showing the great capacity of chemically activated solid phase obtained by HTC of corn Stover at $250{ }^{\circ} \mathrm{C}, 240$ minutes, biomass-to-water ratio of $1: 10$, to adsorb organic compounds present in HTC process water-streams. The results are according to similar studies reported by Islam et al. [64-65], who investigated the adsorption of MB (Methylene Blue) from aqueous solution with hydro-char from factory-rejected tea (FRT) and palm date seeds (PDS), chemically activated with sodium hydroxide. The adsorption kinetic described by a
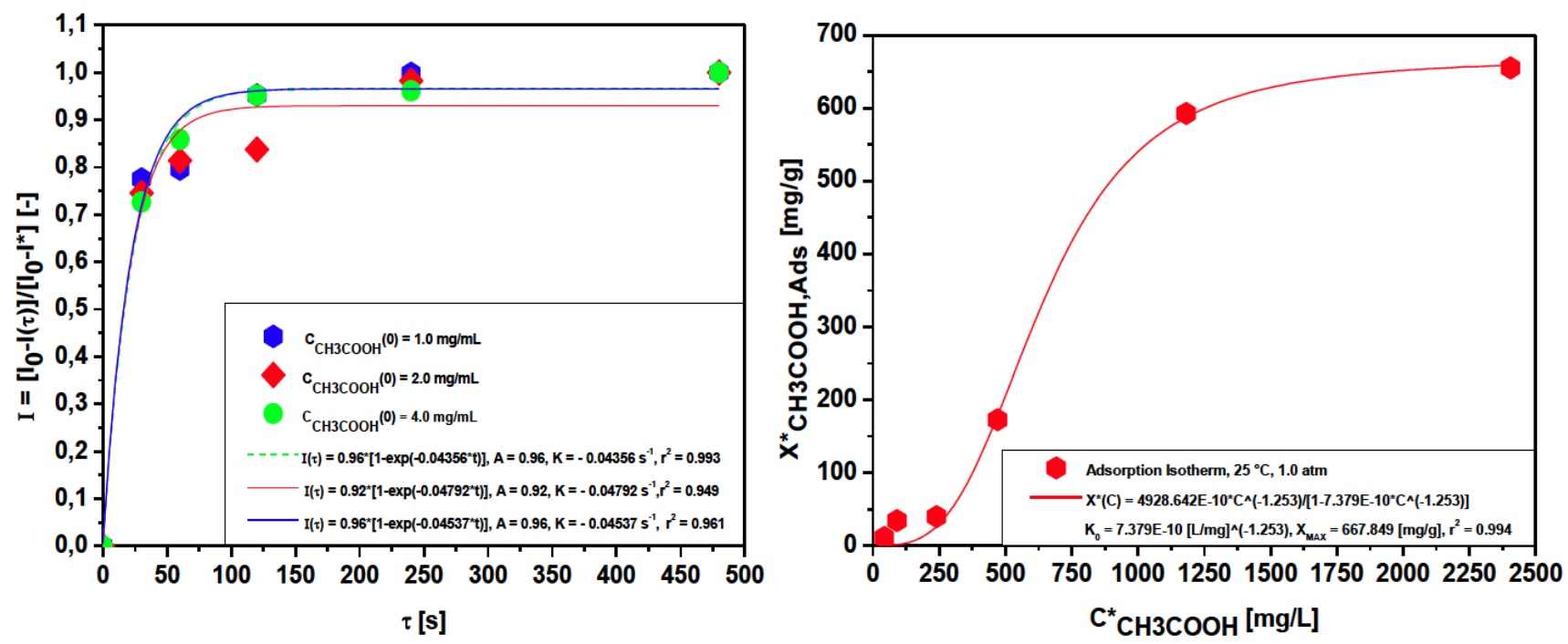

Figure 7: Kinetic and adsorption isotherm of acetic acid solutions on the solid phase product obtained by HTC of corn Stover at $250{ }^{\circ} \mathrm{C}, 240$ minutes reaction time, biomass-to-water ratio of $1: 10$, activated with $2.0 \mathrm{M} \mathrm{NaOH}$. 
pseudo-second-order model and the adsorption isotherms by the Langmuir [64], and the Freundlich models [65], respectively. The authors reported a maximum adsorption capacity of $487.4 \mathrm{mg} / \mathrm{g}$ at $30{ }^{\circ} \mathrm{C}$ [64], and $612.1,464.3$ and $410.0 \mathrm{mg} / \mathrm{g}$ at 30,40 and 50 ${ }^{\circ} \mathrm{C}$ [65], respectively, being the results according to the measured maximum adsorbent capacity of $650 \mathrm{mg} / \mathrm{g}$ at $30{ }^{\circ} \mathrm{C}$. Recently, Liang et al. [66] investigated the adsorption of acetic acid on carbon microspheres synthetized by HTC, obtaining maximum adsorbent capacity of $260 \mathrm{mg} / \mathrm{g}$ at $25^{\circ} \mathrm{C}$.

\section{CONCLUSIONS}

The solid phase yield decreases with temperature, while that of liquid phase increases, presenting an inflection region between 200 and $225^{\circ} \mathrm{C}$, showing that hydrothermal carbonization occurred between 200 and $225{ }^{\circ} \mathrm{C}$, while hydrothermal liquefaction dominates between 225 and $250{ }^{\circ} \mathrm{C}$. SEM images of solid phase product at $250{ }^{\circ} \mathrm{C}$ show an aggregate amorphous solid phase with substantial changes on the original morphology of corn Stover. The XRD results show that higher temperatures favors the formation of mineralogical phase Graphite (C). HHV of solid phase products increases with temperature, showing a densification in the energy material of approximately $34.32 \%$. GC analysis identified acetic acid in concentrations between 4020-5040 mg/L. HPLC identified the presence of furfurals, and HMF, whose concentrations decreases exponentially and linearly with temperature, being both compounds not detectable at $250{ }^{\circ} \mathrm{C}$. The chemically activated solid phase was selective to adsorb acetic acid, showing that recovery of acetic acid from aqueous solution produced after hydrothermal processing of biomass is feasible by using a multistage-stage adsorption process in series.

\section{ACKNOWLADGMENT}

CNPq-Brazil for the financial support (Scholarship $N^{\circ}$. 207325/2014-6). The first author express his gratitude to Dr. rer. agr. Thomas Hofmman, Director of Department of Postharvest Technology at ATBPotsdam, for giving the opportunity to research at the Laboratory of Biochar.

\section{REFERENCES}

[1] Hettenhaus JR, Wooley R, Wiselogel A. Biomass commercialization prospects in the next 2 to 5 years: Biomass colloquies 2000 [Online]. NREL/ACO-9-29-03901. Posted 2000 Oct 10. Available http://www.afdc.doe.gov/ pdfs/4809.pdf
[2] Dipardo J. Outlook for biomass ethanol production and demand. Washington, DC: Energy Information Agency 2000. Available at http://www.eia.doe.gov/oiaf/analysispaper/pdf/ biomass.pdf.

[3] Perlack RD, Wright LL, Turhollow AF, Graham RL, Stokes BJ, Erbach DC. Biomass as a feedstock for a bioenergy and bio-products industry: The technical feasibility of a billion-ton annual supply. Tech. Rep. ORNL/TM 2006/66, Oak Ridge National Laboratory, Oak Ridge, TN, 2005.

[4] Chundawat SPS, Venkatesh B, Dale BE. Effect of particle size based separation of milled corn stover on AFEX pretreatment and enzymatic digestibility. Biotechnol Bioeng 2007; 96: 219-231. http://dx.doi.org/10.1002/bit.21132

[5] Kim S, Dale BE. Global potential bioethanol production from wasted crops and crop residues. Biomass Bioenergy 2004; 26: 361-375. http://dx.doi.org/10.1016/j.biombioe.2003.08.002

[6] Gallager P, Dikeman M, Fritz J, Wailes E, Gauther W, Shapouri $\mathrm{H}$. Biomass from crop residues: cost and supply estimates. Agricultural Economic Report 819, USDA, Washington, DC: 2003.

[7] USDA, FAS Grain: World Markets and Trade. http://apps.fas.usda.gov/psdonline/circulars/grain.pdf

[8] Sokhansanj S, Mani S, Tagore S, Turhollow AF. Technoeconomic analysis of using corn stover to supply heat and power to a corn ethanol plant-Part 1: Cost of feedstock supply logistics. Biomass Bioenergy 2010; 34: 75-8. http://dx.doi.org/10.1016/j.biombioe.2009.10.001

[9] Varga E, Klinke HB, Reczey K, Thomsen AB. High solid simultaneous Saccharification and Fermentation of wet oxidized corn Stover to ethanol. Biotechnol Bioeng 2004; 88: $567-574$.

http://dx.doi.org/10.1002/bit.20222

[10] Narayanaswamy N, Faik A, Goetz DJ, Gu TY. Supercritical carbon dioxide pretreatment of corn stover and switchgrass for lignocellulosic ethanol production. Bioresour Technol 2011; 102: 6995-7000.

http://dx.doi.org/10.1016/j.biortech.2011.04.052

[11] Jin MJ, Balan V, Gunawan C, Dale BE. Consolidated bioprocessing (CBP) performance of Clostridium phytofermentans on AFEX-treated corn Stover for ethanol production. Biotechnol Bioeng 2011; 108: 1290-1297. http://dx.doi.org/10.1002/bit.23059

[12] Wan C, Li Y. Microbial pretreatment of corn stover with Ceriporiopsis subvermispora for enzymatic hydrolysis and ethanol production. Bioresour Technol 2010; 101: 63986403. http://dx.doi.org/10.1016/j.biortech.2010.03.070

[13] Qureshi N, Saha BC, Hector RE, Dien B, Hughes S, Liu S, et al. Production of butanol (a biofuel) from agricultural residues: Part II-use of corn stover and switchgrass hydrolysates. Biomass Bioenergy 2010; 34: 566-571. http://dx.doi.org/10.1016/j.biombioe.2009.12.023

[14] Kaliyan N, Morey RV. Natural binders and solid bridge type bindingmechanisms in briquettes and pellets made from corn stover andswitchgrass. Bioresour Technol 2010; 101: 108290

http://dx.doi.org/10.1016/j.biortech.2009.08.064

[15] Theerarattananoon K, Xu F, Wilson J, Ballard R, Mckinney L, Staggenborg $\mathrm{S}$, et al. Physical properties of pellets made from sorghum stalk, corn stover, wheat straw, and big bluestem. Ind Crops Prod 2011; 33: 325-332. http://dx.doi.org/10.1016/j.indcrop.2010.11.014

[16] Zhang GC, Zhang Q, Sun K, Liu XT, Zheng WJ, et al. Sorption of simazine to corn straw biochars prepared at different pyrolytic temperatures. Enviorn Pollut 2011; 159: 2594-2601.

http://dx.doi.org/10.1016/j.envpol.2011.06.012 
[17] Mullen CA, Boateng AA, Goldberg N, Lima IM, Hicks KB. Bio-oil and bio-char production from corn cobs and stover by fast pyrolysis. Biomass Bioenergy 2010; 34: 67-74. http://dx.doi.org/10.1016/j.biombioe.2009.09.012

[18] Fuertes AB, Arbestain MC, Sevilla M, Macia-Agullo JA, Fiol S, Lopez R, Smernik RJ, Aitkenhead WP, Arce F, Macias F. Chemical and structural properties of carbonaceous products obtained by pyrolysis and hydrothermal carbonisation of corn stover. Aust J Soil Res 2010; 48: 618-626. http://dx.doi.org/10.1071/SR10010

[19] Kumar S, Kothari U, Kong L, Lee, YY, Gupta RB. Hydrothermal pretreatment of switchgrass and corn stover for production of ethanol and carbon microspheres. Biomass Bioenergy 2011; 35: 956-968. http://dx.doi.org/10.1016/j.biombioe.2010.11.023

[20] Mosier N, Hendrickson R, Ho N, Sedlak M, Ladisch MR. Optimization of $\mathrm{pH}$ controlled liquid hot water pretreatment of corn stover. Bioresour Technol 2005, 96: 1986-1993.

http://dx.doi.org/10.1016/j.biortech.2005.01.013

[21] Öhgren K, Bura R, Saddler J, Zacchi G. Effect of hemicellulose and lignin removal on enzymatic hydrolysis of steam pretreated corn stover. Bioresour Technol 2007; 98: 2503-2510.

http://dx.doi.org/10.1016/j.biortech.2006.09.003

[22] Lloyd TA, Wyman, CE. Combined sugar yields for dilute sulfuric acid pretreatment of corn stover followed by enzymatic hydrolysis of the remaining solids. Bioresour Technol 2005; 96: 1967-1977.

http://dx.doi.org/10.1016/j.biortech.2005.01.011

[23] Kim TH, Lee YY. Pretreatment and fractionation of corn stover by ammonia recycle percolation process. Bioresour Technol 2005; 96: 2007-2013.

http://dx.doi.org/10.1016/j.biortech.2005.01.015

[24] Kim TH, Lee YY. Pretreatment of corn stover by soaking in aqueous ammonia at moderate temperatures. Appl Biochem and Biotechnol 2007; 137(1): 81-92. http://dx.doi.org/10.1007/s12010-007-9041-7

[25] Reza MT, Yan W, Uddin MH, Lynam JG, Hoekman SK, Coronella CJ, Vásquez VR. Reaction kinetics of hydrothermal carbonization of loblolly pine. Bioresour Technol 2013; 139: 161-169. http://dx.doi.org/10.1016/j.biortech.2013.04.028

[26] He C, Giannis A, Wang JY. Conversion of sewage sludge to clean solid fuel using hydrothermal carbonization: Hydrochar fuel characteristics and combustion behavior. Appl Energy 2013; 11: 257-266.

http://dx.doi.org/10.1016/j. apenergy.2013.04.084

[27] Parshetti GK, Liu Z, Jain A, Srinivasan MP, Balasubramanian R. Hydrothermal carbonization of sewage sludge for energy production with coal. Fuel 2013; 111: 201-210. http://dx.doi.org/10.1016/j.fuel.2013.04.052

[28] Escala M, Zumbühl $T$, Koller Ch, Junge R, Krebs R. Hydrothermal carbonization as an energy-efficient alternative to established drying technologies for sewage sludge: A feasibility study on a laboratory scale. Energy Fuels 2013; 27(1): 454-460.

http://dx.doi.org/10.1021/ef3015266

[29] Zhao P, Shen Y, Ge S, Yoshikawa K. Energy recycling from sewage sludge by producing solid biofuel with hydrothermal carbonization. Energy Convers Manag 2014; 78: 815-821. http://dx.doi.org/10.1016/j.enconman.2013.11.026

[30] Peterson AA, Vogel F, Lachance RP, Froling M, Antal JMJ, Tester JW. Thermochemical biofuel production in hydrothermal media: a review of sub- and supercritical water technologies. Energ Environ Sci 2008; 1: 32-65. http://dx.doi.org/10.1039/b810100k

[31] Brunner G. Hydrothermal and Supercritical Water Processes. $1^{\text {st }}$ edition. Elsevier, 2014.
[32] Möller M, Nilges P, Harnisch F, Schröder U. Subcritical water as reaction environment. Fundamentals of hydrothermal biomass transformation. ChemSusChem. 2011; 4: 566-579. http://dx.doi.org/10.1002/cssc.201000341

[33] Öztürk I, Irmak S, Hesenov A, Erbatur O. Hydrolysis of kenaf (Hibiscus cannabinus L.) stems by catalytical thermal treatment in subcritical water. Biomass Bioenergy 2010; 34: 1578-1585.

http://dx.doi.org/10.1016/j.biombioe.2010.06.005

[34] Becker R, Dorgerloh U, Paulke E, Mumme J, Nehls I. Hydrothermal Carbonization of Biomass: Major Organic Components of the Aqueous Phase. Chem Eng Technol 2014; 37(3): 511-518.

http://dx.doi.org/10.1002/ceat.201300401

[35] Becker R, Dorgerloch U, Helmis M, Mumme J, Diakité M, Nehls I. Hydrothermally carbonized plant material: patterns of volatile organic compounds detected by gas chromatography. Bioresour Technol 2013; 130: 621-628. http://dx.doi.org/10.1016/j.biortech.2012.12.102

[36] Reza MT, Becker W, Sachsenheimer K, Mumme J. Hydrothermal carbonization (HTC): near infrared spectroscopy and partial least-squares regression for determination of selective components in HTC solid and liquid products derived from maize silage. Bioresour Technol 2014; 161: 91-101.

http://dx.doi.org/10.1016/j.biortech.2014.03.008

[37] Ju YH, Huynh LH, Kasim NS, Guo TJ, Wang JH, Fazary AE. Analysis of soluble and insoluble fractions of alkali and subcritical water treated sugarcane bagasse. Carbohydr Polym 2011; 83: 591-599. http://dx.doi.org/10.1016/j.carbpol.2010.08.022

[38] Phaiboonsilpa N, Yamauchi K, Lu X, Saka S. Two-step hydrolysis of Japanese cedar as treated by semi-flow hotcompressed water. J Wood Sci 2010; 56(4): 331-338. http://dx.doi.org/10.1007/s10086-009-1099-0

[39] Reza MT, Wirth B, Lüder U, Werner M. Behavior of selected hydrolyzed and dehydrated products during hydrothermal carbonization of biomass. Bioresour Technol 2014; 169: 352361.

http://dx.doi.org/10.1016/j.biortech.2014.07.010

[40] Stemann J, Putschew A, Ziegler F. Hydrothermal carbonization: process water characterization and effects of water recirculation. Bioresour Technol 2013; 143: 139-146. http://dx.doi.org/10.1016/j.biortech.2013.05.098

[41] Uddin MH, Reza MT, Lynam JG, Coronella CJ. Effects of water recycling in hydrothermal carbonization of Loblolly pine. Environ Prog Sustain Energy 2013; 33(4): 1309-1315. http://dx.doi.org/10.1002/ep.11899

[42] Wirth B, Mumme J. Anaerobic digestion of wastewater from hydrothermal carbonization of corn silage. Appl Bioenergy 2014; 1(1): 1-10.

http://dx.doi.org/10.2478/apbi-2013-0001

[43] Schneider D, Escala M, Supawittayayothin K, Tippayawong $\mathrm{N}$. Characterization of biochar from hydrothermal carbonization of bamboo. Int J Energy Environ 2011; 2(4): 647-652.

[44] Funke A, Reebs F, Kruse A. Experimental comparison of hydrothermal and vapothermal carbonization. Fuel Process Technol 2013; 115: 261-269. http://dx.doi.org/10.1016/j.fuproc.2013.04.020

[45] Falco C, Bacille N, Titirici MM. Morphological and structural differences between glucose, cellulose and lignocellulosic biomass derived hydrothermal carbons. Green Chem 2011; 13: 3273-3281. http://dx.doi.org/10.1039/c1gc15742f

[46] Liu Z, Balasubramanian R. Upgrading of waste biomass by hydrothermal carbonization (HTC) and low temperature pyrolysis (LTP): A comparative evaluation. Appl Energy 2014; 114: 857-864.

http://dx.doi.org/10.1016/j.apenergy.2013.06.027 
[47] Minowa T, Fang Z, Ogi T, Vàrhegyi G. Decomposition of cellulose and glucose in hot-compressed water under catalyst-free conditions. JChem Eng Jpn 1998; 31(1): 131134.

http://dx.doi.org/10.1252/jcej.31.131

[48] Yu Y, Wu H. Significant differences in the hydrolysis behavior of amorphous and crystalline portions within microcrystalline cellulose in hot-compressed water. Ind Eng Chem Res 2010; 49: 3902-3909.

http://dx.doi.org/10.1021/ie901925g

[49] $\mathrm{Yu} \mathrm{Y,} \mathrm{Lou} \mathrm{X,} \mathrm{Wu} \mathrm{H.} \mathrm{Some} \mathrm{recent} \mathrm{advances} \mathrm{in} \mathrm{hydrolysis} \mathrm{of}$ biomass in hot-compressed water andits comparisons with other hydrolysis methods. Energy Fuels 2008; 22: 46-60. http://dx.doi.org/10.1021/ef700292p

[50] Zhang B, Huang HJ, Ramaswamy S. Reaction kinetics of the hydrothermal treatment of lignin. Appl Biochem Biotechnol 2008; 147: 119-131. http://dx.doi.org/10.1007/s12010-007-8070-6

[51] Oliveira I, Blöhse D, Ramke HG. Hydrothermal carbonization of agricultural residues. Bioresour Technol 2013; 142: 138146.

http://dx.doi.org/10.1016/j.biortech.2013.04.125

[52] Mota SAP, Mâncio AA, Lhamas DEL, Abreu DH, Silva MS, Santos WG, Castro DAR, Oliveira RM, Araújo ME, Borges LEP, Machado NT. Production of green diesel by thermal catalytic cracking of crude palm oil (Elaeis guineensis Jacq) in a pilot plant. J Anal Appl Pyrolysis 2014; 110: 1-11. http://dx.doi.org/10.1016/j.jaap.2014.06.011

[53] Almeida HS, Corrêa OA, Eid JG, Ribeiro HJ, Castro DAR, Pereira MS, Pereira LM, Mâncio AA, Santos MC, Souza JAS, Borges LEP, Mendonça NM, Machado NT. Production of Biofuels by Thermal Catalytic Cracking of Scum from Grease Traps in Pilot Scale. J Anal Appl Pyrolysis Journal 2016; 118: 20-33.

http://dx.doi.org/10.1016/j.jaap.2015.12.019

[54] Mani S, Tabil LG, Sokhansanj S. Grinding performance and physical properties of wheat and barley straws, corn stover and switchgrass. Biomass Bioenergy 2004; 27: 339-352. http://dx.doi.org/10.1016/j.biombioe.2004.03.007

[55] Yang B, Wyman CE. Effect of xylan and lignin removal by batch and flowthrough pretreatment on the enzymatic digestibility of corn stover cellulose. Biotechnol Bioeng 2004; 86(1): 88-98.

http://dx.doi.org/10.1002/bit.20043

[56] Varga E, Szengyel Z, Réczey K. Chemical pretreatment of corn stover for enhancing enzymatic digestability. Appl Biochem and Biotechnol 2002; 98(1): 73-87. http://dx.doi.org/10.1385/ABAB:98-100:1-9:73
[57] Angın D, Şensöz S. Effect of pyrolysis temperature on chemical and surface properties of biochar of rapeseed (Brassica napus L.). Int J Phytoremediation 2014; 16: 684693.

http://dx.doi.org/10.1080/15226514.2013.856842

[58] Liu Z, Zhang FS, Wu J. Characterization and Application of Chars Produced from Pinewood Pyrolysis and Hydrothermal Treatment. Fuel 2010; 89 (2): 510-514. http://dx.doi.org/10.1016/j.fuel.2009.08.042

[59] Xiao LP, Shi ZJ, Xu F, Sun RC. Hydrothermal carbonization of lignocellulosic biomass. Bioresour Technol 2012; 118: 619-623. http://dx.doi.org/10.1016/j.biortech.2012.05.060

[60] Hoskinson RL, Karlen DL, Birrell SJ, Radtke CW, Wilhelm WW. Engineering, nutrient removal, and feedstock conversion evaluations of four corn stover harvest scenarios. Biomass Bioenergy 2007; 31: 126-136. http://dx.doi.org/10.1016/j.biombioe.2006.07.006

[61] Mumme J, Eckervogt L, Pielert J, Diakité M, Rupp F, Kern J. Hydrothermal carbonization of anaerobically digested maize silage. Bioresour Technol 2011; 102: 9255-9260.

http://dx.doi.org/10.1016/j.biortech.2011.06.099

[62] Reza MT, Uddin MH, Lynam JG, Hoekman SK, Coronella C. Hydrothermal carbonization of loblolly pine: reaction chemistry and water balance. Biomass Conv Bioref 2014; 4(4): 311-321.

http://dx.doi.org/10.1007/s13399-014-0115-9

[63] Funke A, Ziegler F. Hydrothermal carbonization of biomass: A summary and discussion of chemical mechanisms for process engineering. Biofuels Bioprod Bior 2010; 4(2): 160177. http://dx.doi.org/10.1002/bbb.198

[64] Islam MA, Tan I, Benhouria A, Asif M, Hameed BH. Methylene Blue adsorption on factory-rejected activated carbon prepared by conjunction of hydrothermal carbonization and sodium hydroxide activation process. J Taiwan Inst Chem Eng 2015; 52: 57-64. http://dx.doi.org/10.1016/j.jtice.2015.02.010

[65] Islam MA, Tan I, Benhouria A, Asif M, Hameed BH. Mesoporous and adsorptive properties of palm date seed activated carbon prepared via sequential hydrothermal carbonization and sodium hydroxide activation. Chem Eng J 2015; 270: 187-195. http://dx.doi.org/10.1016/j.cej.2015.01.058

[66] Liang JL, Liu YH, Zhang J. Effect of solution $\mathrm{pH}$ on the carbon microsphere synthesized by hydrothermal carbonization. Procedia Environ Sci 2011; 11: 1322-1327. http://dx.doi.org/10.1016/j.proenv.2011.12.198 